\title{
A COMPARATIVE STUDY OF ARTIFICIAL NEURAL NETWORKS AND MULTIPLE REGRESSION ANALYSIS FOR MODELING SKIDDING TIME
}

\author{
ÇALIŞKAN, E. ${ }^{1 *}-$ SEVIM, Y. ${ }^{2}$ \\ ${ }^{1}$ Department of Forest Engineering, Faculty of Forestry, Karadeniz Technical University \\ 61080 Trabzon, Turkey \\ ${ }^{2}$ Faculty of Engineering, Karadeniz Technical University, 61080 Trabzon, Turkey \\ *Corresponding author \\ e-mail: caliskan@ktu.edu.tr \\ (Received 23 $3^{\text {rd }}$ Oct 2018; accepted 20 $0^{\text {th }}$ Dec 2018)
}

\begin{abstract}
One of the most important functions of forests is providing raw material for wood. Timber extraction is among the most technically demanding, expensive and time consuming activities for wood raw material production. The analysis of timber extraction activities is complex and it is quite difficult to model them. Therefore, Artificial Neural Networks (ANN) frequently used as a modelling tool in the analysis of complex problems have been used to solve this issue. The aim of this study is to investigate the feasibility of ANN's including Multilayer Perceptron (MLP), Cascade Forward Back Propagation (CFBP) and compare the predictions for total time during log skidding operations stations in Eastern Black sea region (Giresun Forest District Directorates) of Turkey with those of the Multiple Regression Analysis (MRA). Moreover, standard times are calculated, and affective factors are determined, after which the effectiveness levels are evaluated at each working stage by way of timing determinations when skidder is used for timber extraction. The comparison of models were carried out by using the correlation coefficient, mean squared error, root mean square errors and mean absolute error. The comparison results indicate that MLP and CFBP models are better at predicting the total time during log skidding operations in comparison with the MRA model. These results have put forth that artificial neural networks have a greater prediction in comparison with multiple regression analysis for predicting the skidding time in timber extraction operations and that less erroneous results are obtained. It is observed that artificial neural networks can be preferred in cases for which the multiple regression analysis predictions have not been met and the analysis cannot be performed.
\end{abstract}

Keywords: timber extraction, log skidding, multilayer perceptron, cascade forward back propagation, Turkey

\section{Introduction}

Turkey has a total of 22.7 million hectares of forest area, which makes up $27 \%$ of its total land area. Almost $46 \%$ of the total area is on steep land with slopes greater than $40 \%$. Thus, harvesting in mountainous regions has always played a significant role (GDF, 2017). Forestry operations in Turkey are carried out under different conditions on a forest area of approximately 22.7 million hectares, located at different parts of the country (Çalışkan et al., 2017).

Timber harvesting, as a succession of interrelated and interdependent operations in timber production, felling, processing and timber transport. Timber transport consists of two sub phases: timber extraction and further transport that are mutually dependent (Bayoğlu, 1962; Seçkin, 1978; FAO, 1982; Erdaş, 1986; Haarlaa and Jurvelius, 1987; Acar, 1994; Dykstra and Heinrich, 1996; Heinimann, 1999; Karaman, 2001; Heinimann and Stampfer, 2003; Pentek, 2008; Çalışkan et al., 2017). 
Different tools and methods are used according to technical, economic and environmental factors for timber extraction operations which is one of the stages of wood raw material production. Skidding the wood raw material on skid trails via forest tractors or agricultural tractors to place on temporary stacking locations (ramp) is one of these methods. Land topography is among the most distinctive factors in skidding work. Timber extraction methods are generally determined according to ground slope classes. The slope groups taken as basis for determining production type are as follows: using agricultural tractor and animals for skidding 0-33\% ground slope, using skidder (MB Trac 900) for cable drawing 34-50\% ground slope and cable timber extraction $50 \%<$ ground slope (Erdas et al., 1986; Heinimann, 1999). Timber extraction is the most difficult and expensive stages of producing wood raw material and also has the highest environmental damage. A planned approach is required for shortening this process, making the work easier, improving efficiency and thus attaining an economical process (Marchi et al., 2014).

When wood raw material skidding activities are taken into consideration with a system approach, there is a necessity for determining the standard times for different conditions that can be used while planning, applying and inspecting skidding activities which will also form a basis to ensure that skidding workers receive equal pay under equal conditions. Effectiveness of operating conditions while calculating standard time is quite high especially for mountainous forests. Determining the wages according to these factors is of vital importance for ensuring wage justice among employees and for the cost effectiveness of forest management for employers. There are various studies on timber extraction operations in which time studies have been carried out for cable drawing via agricultural tractors and forest tractors (Acar, 1995, 1997; Karaman, 1997; Öztürk, 2005; Tunay et al., 2002; Öztürk, 2010; Çağlar, 2016).

ANN is used as a popular method in different engineering applications by many researchers. ANNs are software designed for simulating the operation of simple biological neural systems (Yurtoğlu, 2006). The main reason why a human being may develop solutions for issues that require thinking and observation skills is his/her ability to learn through experience (Sağıroğlu et al., 2003). Therefore, ANN may be a beneficial tool in engineering applications (Topçu and Sarıdemir, 2008). ANN is a strong tool especially for data models with low regression coefficients (Esteban et al., 2009). ANN's are used for modelling complex operations in many engineering fields ranging from aeronautics, electronic, production, robotics, communication, construction, forest etc.

ANN's was successfully implemented in the field of forest modelling. Particularly, ANN approach has been used for many objectives modeling individual tree survival probabilities (Guan and Gertner, 1991), forest age using TM images (Jensen et al., 1999), tree mortality (Hasenauer et al., 2001; Castro et al., 2013), forecasting of industrial wood demand (Güngör et al., 2004), pine bark volume (Diamantopoulou, 2005), tree volume (Diamantopoulou, 2005a; Diamantopoulou and Milios, 2010; Özçelik et al., 2008, 2010), tree stem diameters (Diamantopoulou, 2005b; Leite et al., 2011), tree felling times (Karaman and Çalışkan, 2009), tree heights (Diamantopoulou and Özçelik, 2012; Özçelik et al., 2013), diameter distributions (Cai et al., 2012) predict of skidding time (Naghdi and Ghajar, 2012), trunk volume estimates (Bayati and Najafi, 2013), prediction of cable drawing time (Bayati and Najafi, 2015), tree diameter increments (Ercanlı et al., 2016), describing diameter distribution (Bolat et al., 2016), bark volume estimation (Çatal et al., 2018). 
The use of artificial neural networks in timber extraction is at a starting stage in Turkey. Hence, there are a few studies in forestry literature which compare the performance of artificial neural networks with other models. For this reason, the aim of this study was to investigate the feasibility of two different reputed types of ANN's and compare the results with those of MRA for predicting the total time during log skidding operations stations. Thus, the network architecture, training algorithm and transfer function that yielded the best result were determined. The data set was separated into three sets as training, test and validation. The training data set used for the training of ANN which makes up the majority of the input data set is used to maximize the ability of the network to predict the correct results and the minimize the error. Test data set is not considered during learning and is used to test the success rate for the prediction of the network after the learning stage. Control data set used during the training of the network. If the performance of the trained data set is very low, but the performance of the control set is high; this raises a suspicion that the network has memorized. In such cases, the network has to be trained again (Çelik, 2004).

\section{Material and Methods}

\section{Study Area}

This study was carried out at the Anbardağ forest planning unit covering an area of approximately 5975.0 ha in the Giresun province in the north-eastern Black Sea region of Turkey. The area is located between $40^{\circ} 42^{\prime} 47^{\prime \prime}-40^{\circ} 30^{\prime} 13^{\prime \prime}$ North, and $38^{\circ} 01^{\prime} 49^{\prime \prime}$ $-38^{\circ} 13^{\prime} 16^{\prime \prime}$ East. The average terrain gradient is $30 \%$, and altitudes range from 1.100 $\mathrm{m}$ to $1.500 \mathrm{~m}$ above sea level. Dominant tree species used for production purposes are natural oriental spruce (Picea orientalis Link.) and oriental beech (Fagus orientalis Lipsky). Felling and delimbing operations were carried out via chainsaws. Agricultural and skidder (MB Trac 900) are mostly represented as off-road machines and have been widely used (Çalışkan et al., 2017.

\section{Field Data Collection}

Timber extraction was done by skidder with cable drawing and on-road skidding system. Measured data for the timber operations have been recorded in study forms. Time values for each stage have been measured as 1/100 minute (PM) using a chronometer, the amount of work done has been determined in units and as $\mathrm{m}^{3}$, factors that have an impact on the work done (tree type, diameter, height, ground slope, cable drawing distance, number of logs, log volume, skidding distance) have also been recorded in the work form. No intervention was made on the workers regarding issues such as starting and stopping of work, breaks, pauses, dealing with other operations.

Variables that were considered to have an impact on the work time for skidder timber extraction operations have been evaluated as $X_{i i}\left(X_{11}-X_{17}\right)$ and expressed in numerical values. These variables have been briefly explained in Table 1 .

Continuous time measurement method was used for time measurements and the work phases, total turn time and waiting times were determined using a digital chronometer. The measured time values were for a two person working group with units of 1/100 minute. Work phases and related time values have been expressed as $y_{i i}\left(y_{11}-y_{21}\right)$ for tractor timber extraction operations and related time values have been briefly explained in Table 1. 
Measurements and observations have been carried out related with the timber extraction operations for spruce trees using skidder (preparation time on skidder, pulling time to empty cable, hooking time, time to take the load, wait time to obstacle, waiting time to cable dissolution, waiting time, skidding time, unhooking time, stacking time).

Table 1. Work phases and their descriptive statistics

\begin{tabular}{|c|c|c|c|c|c|c|c|c|c|}
\hline Work phases & Aver. & $\begin{array}{l}\text { Std. } \\
\text { Dev. }\end{array}$ & $\min$. & $\max$. & Work phases & Aver. & $\begin{array}{l}\text { Std. } \\
\text { Dev. }\end{array}$ & $\min$. & $\max$. \\
\hline $\begin{array}{l}\mathrm{y}_{11}: \text { Preparation time } \\
\text { on Tractor }\end{array}$ & 72.00 & 49.74 & 0.00 & 205.0 & $\begin{array}{c}y_{f a}: \text { Total } \\
\text { activity(skidding) } \\
\text { time } \\
\end{array}$ & 936.0 & 462.3 & 250.0 & 2800 \\
\hline $\begin{array}{l}\text { y12: Pulling time to } \\
\text { empty cable }\end{array}$ & 143.0 & 88.28 & 10.00 & 420.0 & $\begin{array}{l}y_{t r}: \text { The tractor is } \\
\text { actively operating } \\
\text { time }\end{array}$ & 327.0 & 157.1 & 60.00 & 730 \\
\hline $\mathrm{y}_{13}:$ Hooking time & 160.0 & 201.8 & 10.00 & 980.0 & $\begin{array}{c}y_{g e}: \text { For cable } \\
\text { drawing, actual } \\
\text { skidding time } \\
\end{array}$ & 609.0 & 357.9 & 130.0 & 2080 \\
\hline $\begin{array}{c}y_{14}: \text { Time to take the } \\
\text { load }\end{array}$ & 146.0 & 88.55 & 20.00 & 470.0 & $\begin{array}{c}X_{11}: \begin{array}{c}\text { Cable haulage } \\
\text { distance }\end{array} \\
\end{array}$ & 26.92 & 15.45 & 2.00 & 90.00 \\
\hline $\begin{array}{c}\text { y15: Wait time to } \\
\text { obstacle }\end{array}$ & 60.00 & 12.88 & 0.00 & 550.0 & $X_{12}:$ Land slope & 57.08 & 12.48 & 25.00 & 85.00 \\
\hline $\begin{array}{l}\mathrm{y}_{16}: \text { Waiting time to } \\
\text { cable dissolution } \\
\end{array}$ & 9.00 & 36.65 & 0.00 & 210.0 & $X_{13}:$ Diameter of logs & 51.48 & 19.70 & 17.00 & 100.00 \\
\hline $\begin{array}{c}\mathrm{y}_{17}: \text { Load take-off } \\
\text { time }\end{array}$ & 34.00 & 64.83 & 0.00 & 300.0 & $X_{14}:$ Length of logs & 6.61 & 3.90 & 1.00 & 24.00 \\
\hline $\mathrm{y}_{18}$ : Waiting time & 192.0 & 731.8 & 0.00 & 6340 & $X_{15}:$ Number of $\log$ & 3.15 & 3.09 & 1.00 & 15.00 \\
\hline y19: Skidding time & 40.00 & 46.90 & 0.00 & 210.0 & $X_{16}:$ Log volume & 0.96 & 0.72 & 0.09 & 3.74 \\
\hline $\mathrm{y}_{20}:$ Unhooking time & 92.00 & 50.35 & 0.00 & 230.0 & \begin{tabular}{|c|}
$X_{17}:$ Skidding \\
distance on the road \\
\end{tabular} & 9.67 & 11.13 & 0.00 & 50.00 \\
\hline $\mathrm{y}_{21}:$ Stacking time & 36.00 & 68.21 & 0.00 & 250.0 & & & & & \\
\hline
\end{tabular}

In addition, times for work groups have been determined as such by combining certain work phases:

Active operating time for the tractor(skidder):

$$
y_{t r}=y_{11}+y_{14}+y_{17}+y_{19}+y_{21}
$$

Real skidding time required for cable drawing:

$$
y_{g e}=y_{12}+y_{13}+y_{14}+y_{15}+y_{16}+y_{20}
$$

Total activity time:

$$
y_{f a}=y_{t r}+y_{g e}
$$

The definitions of all the y parameters mentioned in the equations are shown in Table 1. The ANN models were generated using Matlab software. Statistical analyses were carried out via "SPSS 21.0" software. 


\section{Artificial Neural Network (ANN) modelling approach}

\section{General background}

ANN is a methodology developed based on the biological operating principle of the human brain which is applied on complex problems. An artificial neural network has three main elements: neurons, connections, and training rules (Figure 1) (Dağl1, 1994; Fausett, 1994; Haykin, 1994). In addition, an ANN is comprised of three layers with interconnected neurons which are input layer, output layer and hidden layer. The hidden layer just receive signals from the input layer and send signals to the output layer and their number is determined by way of trials (Benli, 2002).

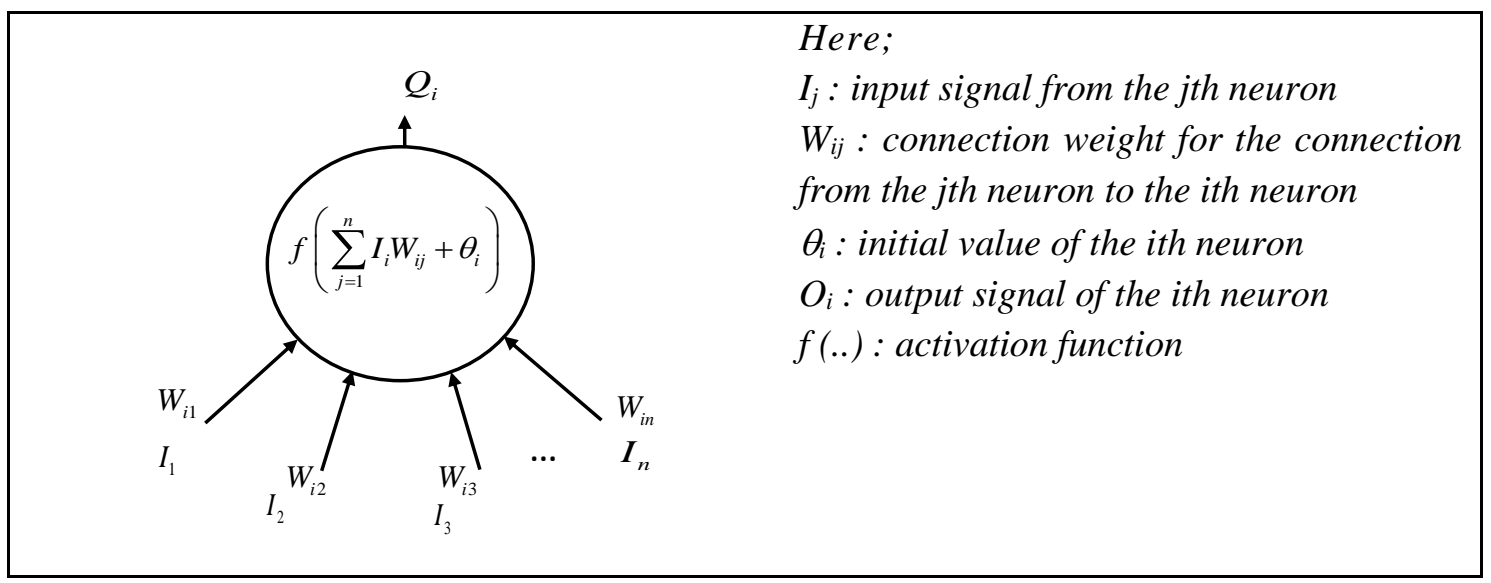

Figure 1. Topology of a Neuron

One of the most important aspects of an ANN is the connections that enable the neurons to transfer data to each other with weight values $\left(w_{j i}\right)$. The weight values have an impact on each input of every operating element (Y1ld1z, 2001). Training of an ANN is defined as making changes in the weights matrix. It can be classified in two groups as supervised and unsupervised learning (Dağl1, 1994; Karaman and Çalışkan, 2009): MLP and CFBP methods have been used in this study for the prediction of the total time during log skidding operations.

\section{Multiple Layer Perceptron (MLP)}

Back propagation (BP) algorithm is used for training MLP networks in this study since it is easy to understand and prove mathematically. The BP artificial neural network models have already been described and are used widely (Rumelhart et al., 1986; Fausett, 1994; Haykin, 1994; Özçelik et al., 2010).

BP algorithm uses two parameters that control the speed at which training takes place. The learning coefficient determines the amount of change in the weights. It is observed that generally values between 0.2 and 0.4 are used and that the value of 0.6 yields the most successful results (Öztemel, 2003). The momentum coefficient plays a role on training performance. It is observed that selecting a value ranging between 0.6 and 0.8 would be best (Öztemel, 2003). Levenberg-Marquardt is highly recommended for neural networks since it is one of the most efficient algorithms (Yu et al., 2011). Levenberg-Marquardt (LM) algorithm has been developed by Kenneth Levenberg and Donald Marquardt (Yu et al., 2011). Considering the features of the problem in this 
study, LM (trainlm) was chosen as the training function. Network architecture, training rate and momentum factor have been determined in our study after examining different combinations. The general structure of MLP is shown in Figure 2.

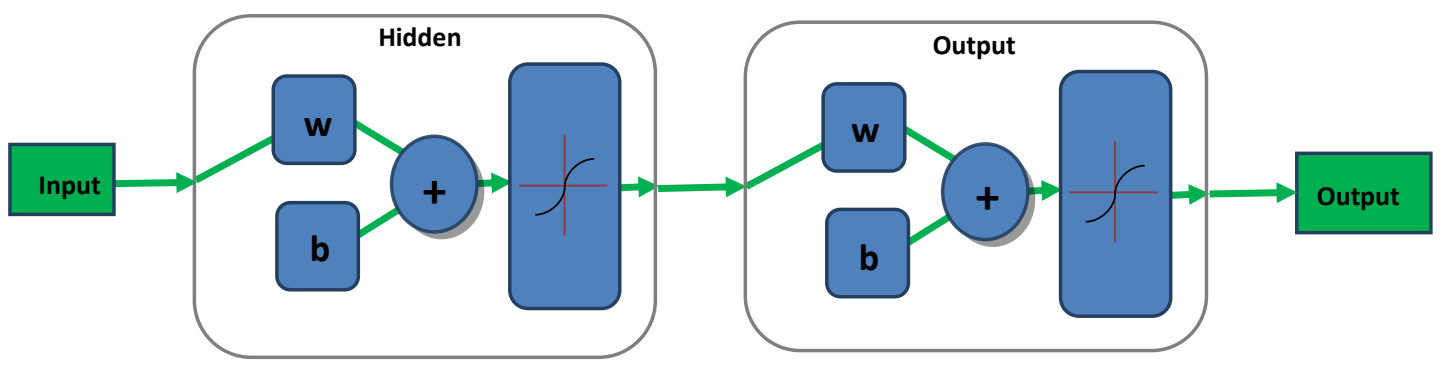

Figure 2. Multilayer Perceptron (MLP) network architecture

\section{Cascade Forward Back Propagation (CFBP)}

Different than MLP, the input values in CFBP are connected with all layers. CFBP has a learning property just like MLP (Figure 3) (Demuth et al., 2009). Considering the features of the problem in this study, LM (trainlm) was chosen as the training function. Network architecture, learning rate and momentum factor were determined in the study after examining different combinations. The general structure of CFBP is shown in Figure 3.

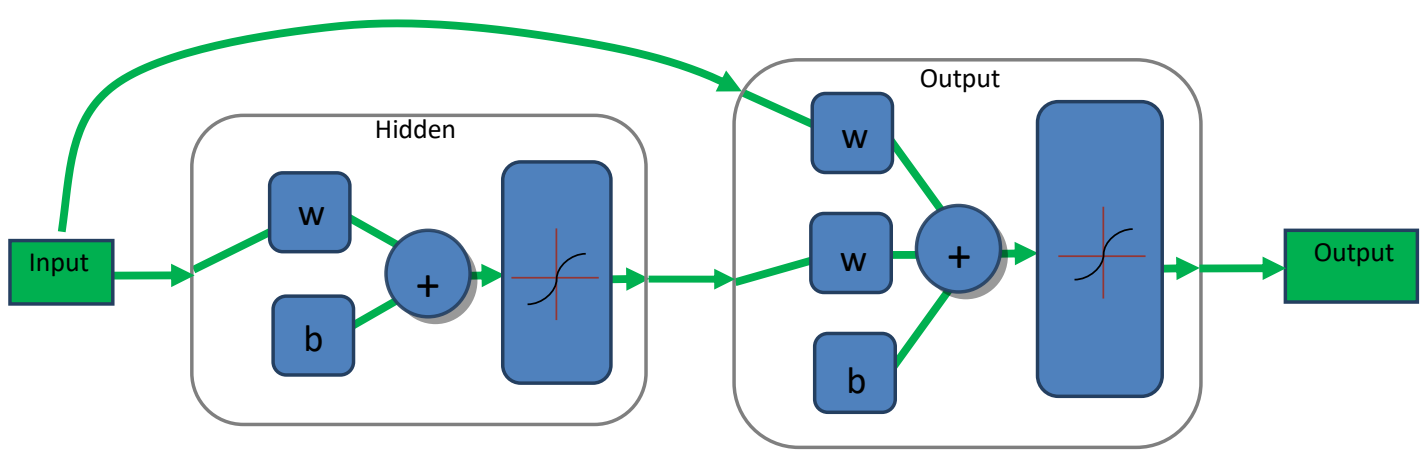

Figure 3. Cascade Forward Back Propagation (CFBP) network architecture

\section{Multiple Regression Analysis (MRA)}

Regression is one of the methods used for testing whether there is a relationship between two or more variables and to express the relationship between the variables by way of linear or curvilinear equations (Öztürkcan, 2009). Regression analysis using more than one independent variable is called multiple regression analysis.

The general structure of the equation in cases when there is more than one independent variable (such as $\left.x_{1}, x_{2}, x_{3}, \ldots\right)$;

$$
Y=\beta_{o}+\beta_{1} x_{1}+\beta_{2} x_{2}+\beta_{3} x_{3}+\ldots+\beta_{n} x_{n} \pm \varepsilon
$$


where $Y$ : Dependent variable, $X_{i}$ : Independent variable $(i=1,2,3 \ldots n) \quad \beta_{i}$ : Regression parameters $(i=1,2,3 \ldots n), \varepsilon$ : Random error and $n$ : number of unknown parameters.

Statistical calculations on variables that are independent from $\left(x_{i i}\right)$ and dependent on $\left(y_{i i}\right)$ measurement results have been carried out as;

- Calculation of the average and deviations.

- Examination of the variables that are effective on the actual time spent for each work phase or the unit time value.

- Examination of the relations between variables.

- And determination of the impact of independent variables on the total time spent for work phases (multiple regression analysis).

\section{Model evaluation criteria}

In this study, the corrected determination coefficient (R), Mean Squared Error (MSE), Root Mean Square Error (RMSE) and mean absolute error (MAE) were used as criteria for comparing artificial neural networks (MLP, CFBP) and multiple regression analysis (MRA). Accordingly, high R and low MSE, RMSE and MAE values indicate the best model. MAE and MSE values were close to 0 and the $\mathrm{R}$ value was close to 1 , thereby indicating that the predicted value strongly converges to the right (Hocking, 1986; Law, 1999; Cho, 2003; Arıkan Karg1, 2014).

a) The Correlation coefficient $(R)$

$$
R=\frac{\sum\left(X_{i}-\bar{X}\right)\left(Y_{i}-\bar{Y}\right)}{\sqrt{\sum\left(X_{i}-\bar{X}\right)^{2}\left(Y_{i}-\bar{Y}\right)^{2}}}
$$

b) Mean Squared Error (MSE)

$$
M S E=\frac{1}{n} \sum_{i=1}^{n}\left(y_{i}-\hat{y}_{i}\right)^{2}
$$

c) Root Mean Square Error (RMSE)

$$
R M S E=\sqrt{\frac{\sum_{i=1}^{n}\left(x_{i}-y_{i}\right)^{2}}{n}}
$$

d) Mean absolute error (MAE)

$$
M A E=\frac{\sum_{i=1}^{n}\left(x_{i}-y_{i}\right)}{n}
$$

where $X_{i}$ and $Y_{i}$ are the observed and predicted data, respectively; $\bar{X}$ and $\bar{Y}$ are the mean of the observed and predicted and $n$ the number of observations in the dataset. 


\section{Results and Discussion}

The arithmetic average, standard deviation, max and min values for the actual time values measured with a unit of 1/100 minutes as the variables of observed values regarding the work phases of cable drawing by forest tractor have been calculated and presented in Table 1.

Single input variance analysis was used to examine whether the impact of the correlation matrix indicating the relationship between the variables and $X_{i i}$ groups on the

values of $y_{i i}$ was statistically significant or not.

The developed ANN models (both MLP and CFBP models) used Cable haulage distance $\left(X_{11}\right)$, Land slope $\left(X_{12}\right)$, Diameter of logs $\left(X_{13}\right)$, Length of $\operatorname{logs}\left(X_{14}\right)$, Number of $\operatorname{logs}\left(X_{15}\right)$, Log volume $\left(X_{16}\right)$ and Skidding distance on the road $\left(X_{17}\right)$, as input variables and the Total activity time (Skidder, $y_{f a}$ ) as the output variable.

In this study, all data were first normalized (0-1) and training, validation and testing data sets that are randomly partitioned into training (65\% of all data). The validation $(10 \%)$ and test data sets (the remaining $25 \%$ ) were used for conquering general patterns between input and output variable while building the ANN model. The training set adjusts the connection weights and the parameters of the model; the validation set checks the performance of the model through the training process and stops the training to avoid overfitting; while the testing set evaluates the trained ANN performance and generalization power (Ghajar et al., 2012a,b; Ghorbani et al., 2016).

A typical MLP model with a BP algorithm is constructed for predicting the total activity time for skidder. The most important characteristic of multi-layered artificial neural networks is that they can be designed to contain more than one hidden layer. However, it has been determined that networks designed with one or two hidden layers display a good performance, whereas networks with more than one or two hidden layers do not have any advantage (Yeşilnaçar et al., 2005; Rumelhart, 1986). The number of neurons in the hidden layer is also an effective element in network performance. In some cases, networks with two hidden layers with a smaller number of neurons may have a better performance in comparison with networks that contain many neurons in one hidden layer (Y1lmaz, 2009).

In this study, the number of neurons in the hidden layer was determined by trial and error. In this context, one hidden layer with 30 neurons was included in the model. Neurons ranging between 1 to 40 were given to each layer for determining the number of neurons included in the hidden layer. Each model was tested 15 times to determine the best model for our study. Therefore, the most suitable model was identified as the model with a 7-30-1 network structure. This study, the hyperbolic tansig transfer function was used between the input and hidden layers, and a pureline transfer function was used between the hidden and output layers. The Levenberg-Marquardt (LM) method was used for the optimization of the algorithms.

In this model, each combination of learning rates and momentum factors were tested for different numbers of hidden neurons. The network was trained in 930 epochs using the LM learning algorithm with a learning rate of 0.001 and a momentum coefficient of 0.3. This was the best combination that conducts to the smaller values of R, MSE, RMSE and MAE in Table 2. Regression values for the data used in the training, validation and testing of the MLP have been given in Figure 4.

Figure 4 shows the $\mathrm{R}$ values graph for the training, test and validation stages of the studied model. The values determined were $R=0.9027$ for the learning stage, $R=0.7767$ 
for the test stage, $\mathrm{R}=0.7427$ for the validity testing of the model and $\mathrm{R}=0.8536$ in total. Figures 5 and 6 show the graphs comparing the model predictions and observed values for the MLP model. It can be observed from Figures 5-6 that the values of the total time during log skidding operations were usually predicted near the observed value.

Table 2. Regression Equalities for calculating the total activity time of timber extraction via skidder

\begin{tabular}{|c|c|c|c|c|c|c|c|c|c|c|}
\hline $\mathrm{Nu}$ & Total Time & $b$ & $X_{11}$ & $X_{12}$ & $X_{13}$ & $X_{14}$ & $X_{15}$ & $X_{16}$ & $X_{17}$ & R-sq \\
\hline 1 & $y_{f a}$ & 55.39 & 15.09 & 2.34 & -3.05 & 6.73 & 26.14 & 385.4 & -1.16 & .777 \\
\hline 2 & $y_{f a}$ & 71.14 & 14.95 & 2.05 & -3.07 & 6.21 & 26.70 & 380.3 & & .776 \\
\hline 3 & $y_{f a}$ & 137.0 & 14.88 & 1.97 & -3.82 & & 26.07 & 404.0 & & .775 \\
\hline 4 & $y_{f a}$ & 261.9 & 14.80 & & -3.90 & & 25.59 & 399.8 & & .773 \\
\hline
\end{tabular}
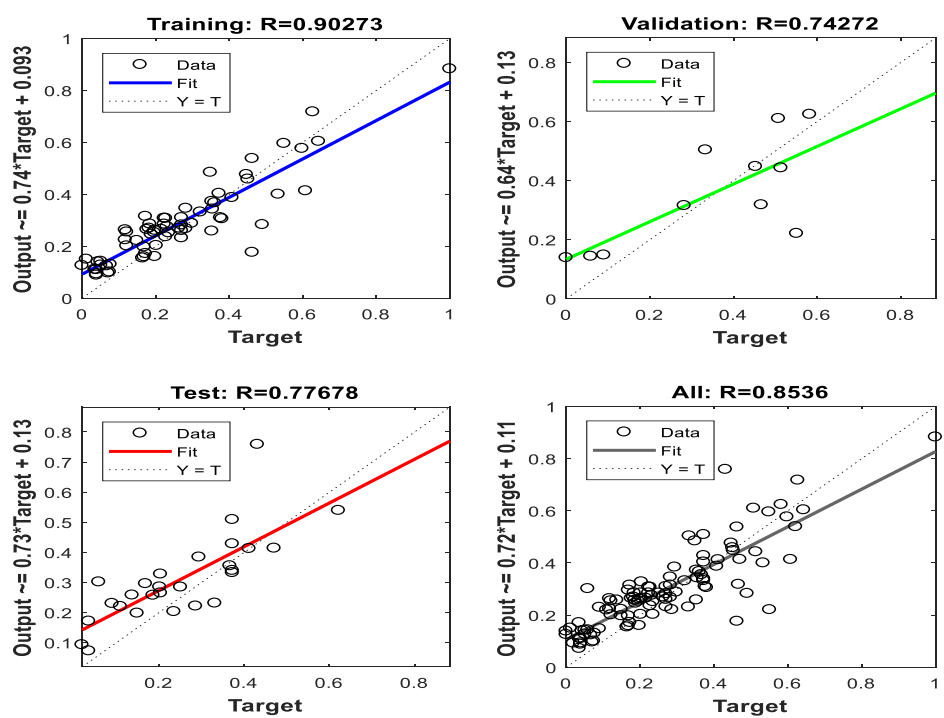

Figure 4. Training, test, validation distribution graphs for the MLP prediction model

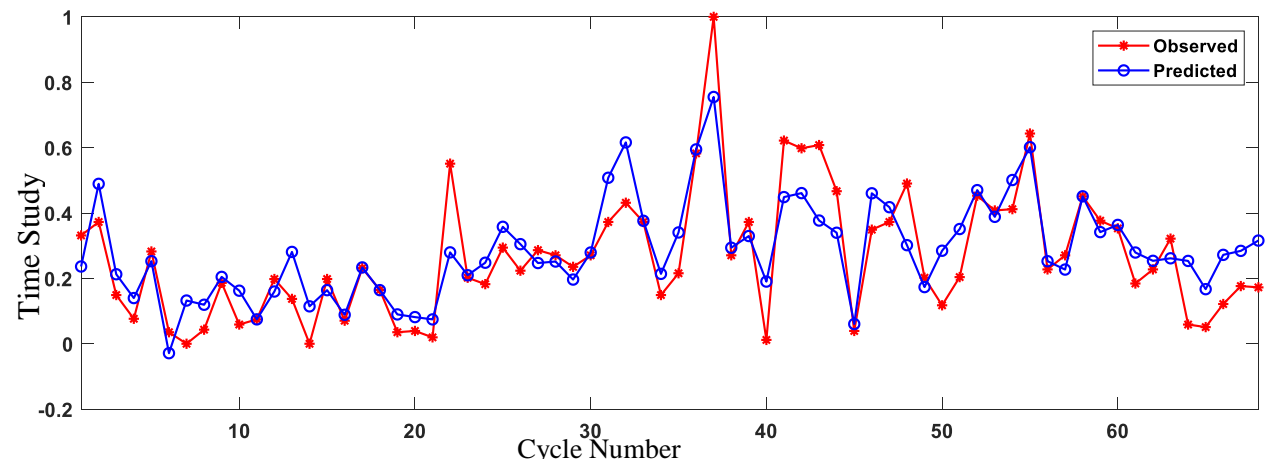

Figure 5. Comparison of predicted(blue line) and observed(red line) values for training sets using MLP 


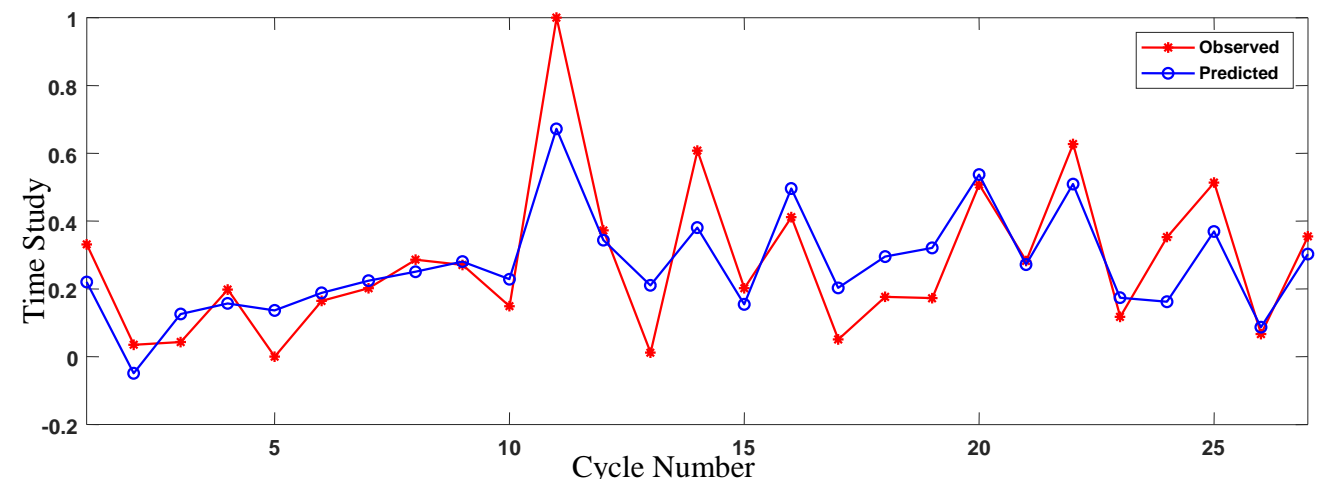

Figure 6. Comparison of predicted (blue line) and observed (red line) values for test sets using $M L P$

The hyperbolic tansig transfer function was used between the input and hidden layers, and a pureline transfer function was used between the hidden and output layers in CFBP model which gave the best results. The LM method was used for the optimization of the algorithms. CFBP model had a single hidden layer with 16 neurons. According to results, the most suitable model for CFBP is 7-16-1 network structure. In this model, the network was trained in 900 epochs using the LM learning algorithm with a learning rate of 0.001 and a momentum coefficient of 0.3 . This was the best combination that conducts to the smaller values of R, MSE, RMSE and MAE in Table 2. Regression values for the data used for the training, validity and testing of the CFBP model have been given in Figure 7.
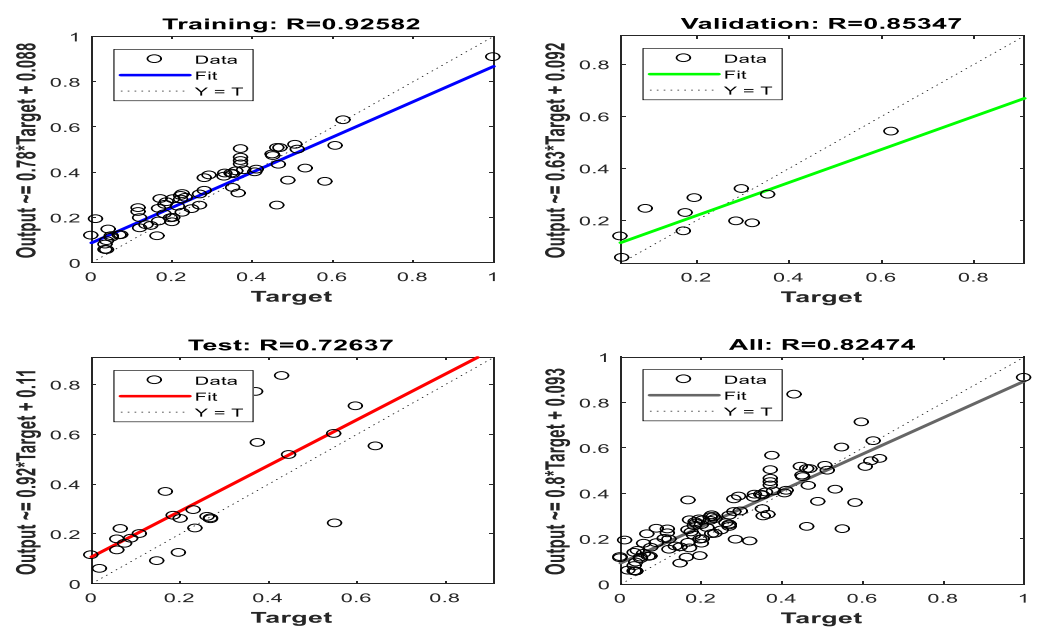

Figure 7. Training, test, validation distribution graphs for the CFBP prediction model

Figure 7 shows the $\mathrm{R}$ value graphs for the training, test and validation $\mathrm{t}$ stages for the studied model. The values determined were $\mathrm{R}=0.9258$ for the learning stage, $\mathrm{R}=0.7263$ for the test stage, $\mathrm{R}=0.8534$ for the validity testing of the model and $\mathrm{R}=0.8247$ in total. Figures 8 and 9 show the graphs comparing the model predictions and observed values for the CFBP model. 
It can be observed from Figure 8-9 that the values of the total time during log skidding operations are usually predicted near the observed value.

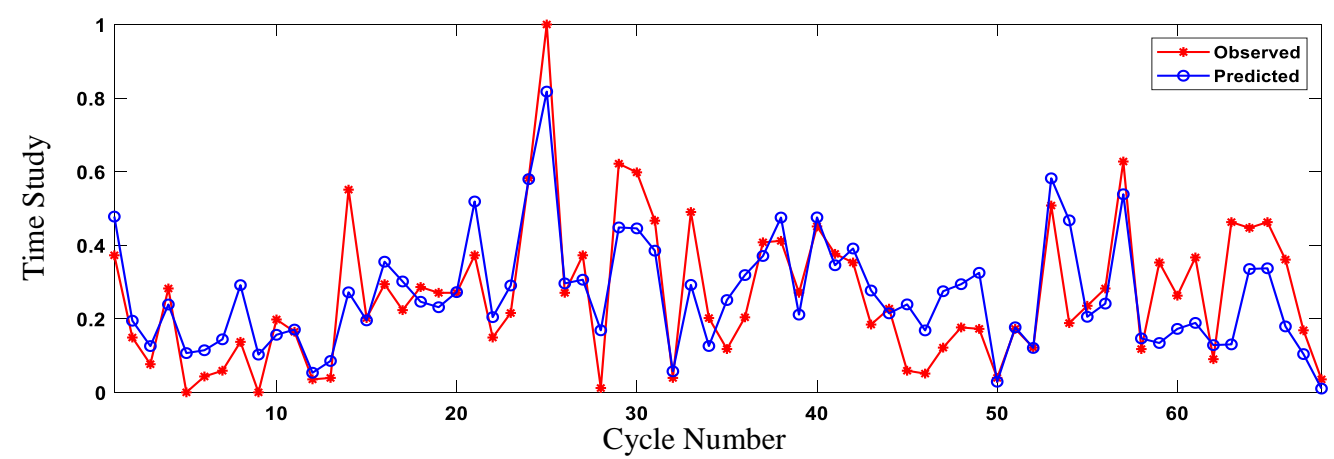

Figure 8. Comparison of predicted and observed values for training sets using CFBP

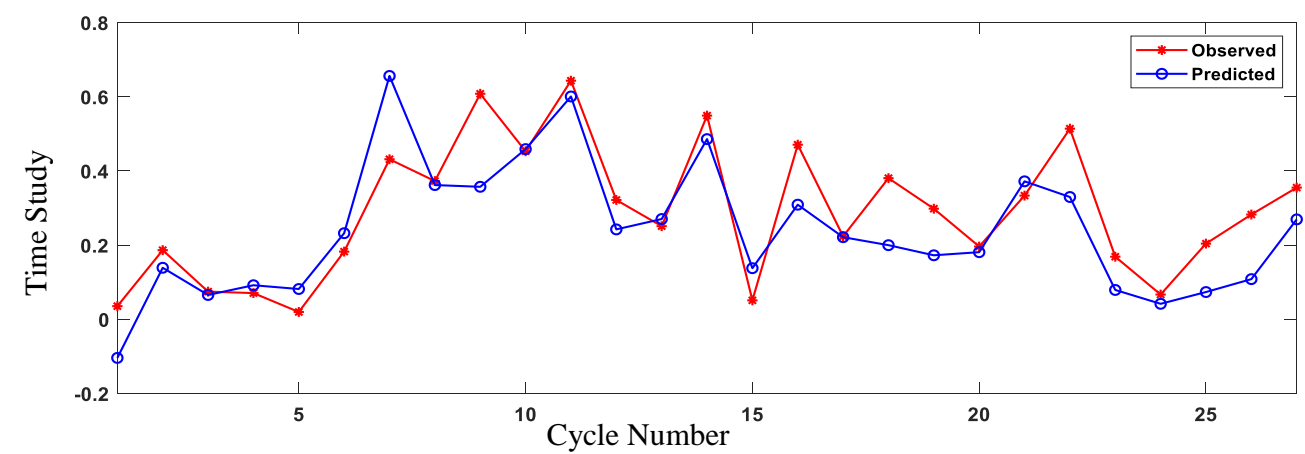

Figure 9. Comparison of predicted and observed values for test sets using CFBP

Alternative equalities have been generated via multiple regression analysis. Operations carried out for the timber extraction total activity time with forest tractor $\left(\mathrm{yfa}_{\mathrm{fa}}\right)$ have been given in detail.

Regression equalities based on the $y_{f a}=f\left(X_{11}, X_{12}, X_{13}, X_{14}, X_{15}, X_{16}, X_{17}\right)$ relationship have been given in Table 3. Consistency of the equation was tested using the coefficients obtained from the regression equation and test data. Graphs that compare the model predictions obtained from the MRA model and the observed values have been given in Figure 10.

Table 3. A Comparison of the MLP, CFBF and MRA Models

\begin{tabular}{c|c|c|c|c|c}
\hline Model & Topology & $\boldsymbol{R}$ & $\boldsymbol{M S E}$ & $\boldsymbol{R M S E}$ & $\boldsymbol{M A E}$ \\
\hline MLP & $7-30-1$ & 0.85 & 0.0098 & 0.0991 & 0.0760 \\
CFBP & $7-16-1$ & 0.82 & 0.0125 & 0.1120 & 0.0784 \\
MRA & $7-1$ & 0.77 & 0.0127 & 0.1126 & 0.0877 \\
\hline
\end{tabular}

It can be observed from Figure 10 that the values of the total time during log skidding operations usually predicted near the observed value. 
The performances for predicting total activity time for skidder are compared using three techniques of MLP, CFBP and MRA. The values of performance measures are given in Table 3.

Values of R, MSE, RMSE and MAE were compared at the end of the study for determining the algorithm with the best performance. MLP had the best performance in the study followed by CFBP and finally MRA with the lowest performance.

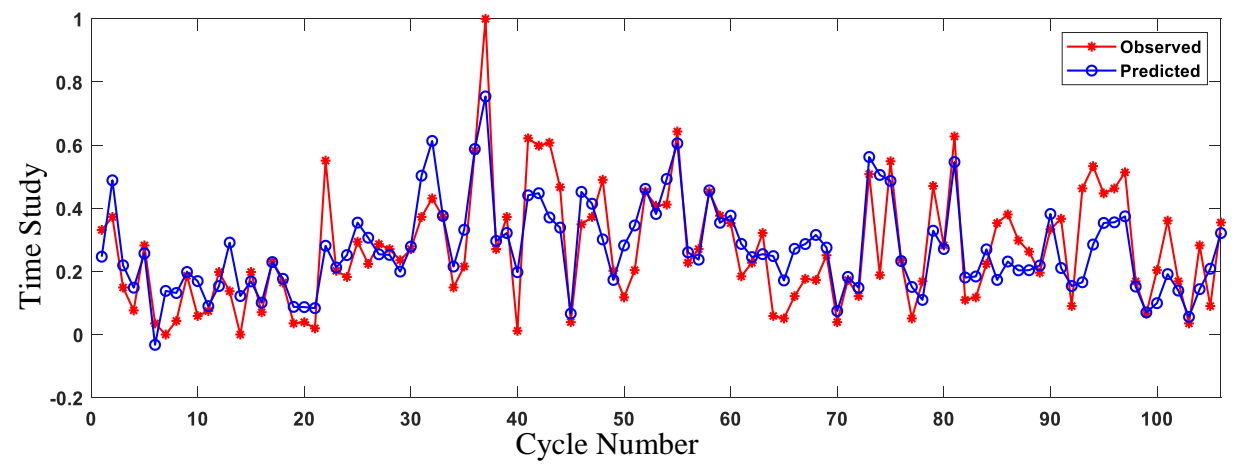

Figure 10. Comparison of predicted and observed values using MRA

\section{Conclusion}

The aim of this study was to investigate the feasibility of two different reputed types of ANNs including MLP, CFBP and compare them with the MRA model with regard to predicting the total time during log skidding operations stations in Eastern Blacksea region (Giresun Forest District Directorates) of Turkey.

Determination coefficient $(\mathrm{R})$ and the expressions that indicate the error variance (MSE, RMSE and MAE) have been taken into consideration for determining the model with the best results. Accordingly, the model with high R and low MSE, RMSE and MAE values was taken into consideration as the best model. The $R$ values obtained in the study were determined to vary between 0.85 and 0.82 for MLP and CFBP and as 0.77 when multiple regression was used.

Thus, it can be observed that artificial neural networks have higher prediction accuracy in comparison with multiple regression analysis and yield results with lower error values. In this case, it can be predicted that artificial neural networks may be preferred in cases when regression analysis predictions are not met and the analysis cannot be carried out.

MLP yielded better results in comparison with CFBP when ANN methods are compared among themselves for the prediction of total time during log skidding operations stations. The results of this study can be used for preparing and inspecting machine operating programs and for calculating production cost. MLP models can be used reliably for calculating the operating time of different land and operating conditions.

The results of this study can be used for determining the time dependent machinery demand to be used in timber extraction operations by private companies, for cost calculation and for putting forth the alternatives to carry out the work at minimum cost. 


\section{REFERENCES}

[1] Acar, H. H. (1994): Developing Forest Transportation Plans in Mountainous Terrain. KTU Fen Bilimleri Enstitusu, PhD Thesis, 150 p., Trabzon. (In Turkish).

[2] Acar, H. H. (1995): Artvin yöresinde MB Trac 900 özel orman traktörü ile orman ürünlerinin bölmeden çıkarılması üzerine incelemeler. - Tr. J. of Agriculture and Forestry 19: 45-52.

[3] Acar H. H. (1997): An investigation on the extraction from compartment by tractors at the mountainous region. - Turkish Journal of Agriculture and Forestry 21: 299-306.

[4] Arıkan Kargi, V. S. (2014): A Comparıson Of Artificial Neural Networks And Multıple Linear Regression Models As In Predictors Of Fabric Weft Defects. - Tekstil ve Konfeksiyon 24(3): 309-316.

[5] Bayati, H., Najafi, A. (2013): Performance Comparison Artificial Neural Networks With Regression Analysis In Trees Trunk Volume Estimation. - Journal Of Forest And Wood Products (Iranian Journal Of Natural Resources) 66(2): 177-191.

[6] Bayati, H., Najafi, A. (2015): Performance evaluation of artificial neural networks for modeling winching time of a Timber Jack 450 C. - Proceedings of the 48th FORMEC Symposium, Oct 4 - 8, Linz, Austria.

[7] Bayoğlu, S. (1962): Cangal Bolgesinde Orman Nakliyatı ve Yol Sistemi Uzerine Araştırmalar. - Orman Genel Mudurluğu Yayınları Sıra No: 334, Seri No: 19, Yenilik Basımevi, İstanbul.

[8] Benli, Y. (2002): Finansal Başarısızlığın Tahmininde Yapay Sinir Ağı Kullanımı ve İMKB'de Bir Uygulama. - Muhasebe Bilim Dünyası Dergisi 4(4): 17-30.

[9] Bolat, F., Ercanl1, İ. (2016): Using Artificial Neural Network in Describing Diameter Distribution in an Even-Aged Forest. - International Forestry Symposium (IFS 2016) Proceedings, 07-10 December: 536-541. Kastamonu/Turkey.

[10] Cai, S., Kang, X., Zhang, L. (2012): Simulation of Trunk diameter distribution for three broadleaved trees based on artificial neural networks. - International Journal of Advancements in Computing Technology 4: 520-527.

[11] Castro, R., Soares, C., Leite, H., Lopes de Souza, A., Nogueira, G., Martins, F. (2013): Individual growth model for Eucalyptus stands in Brazil using Artificial Neural Network. - International Scholarly Research Notices Forestry: 1-12.

[12] Cho, V. (2003): A Comparison of Three Different Approachs to Tourist Arrival Forecasting. - Tourism Management 24: 323-330.

[13] Çağlar, S. (2016): Productivity of the MB Trac 900 Tractor at the Mixed Conifer Stands: An Example of Artvin Forest in Turkey. - International Forestry Symposium (IFS 2016) Proceedings 07-10 December: 601-607. Kastamonu/Turkey.

[14] Çalışkan, E., Karahalil, U. (2017): Evaluatıon Of Forest Road Network And Determining Timber Extraction System Using GIS: A Case Study In Anbardağ Planning Unit. Šumarski list 3-4: 163-171.

[15] Çatal, Y., Saplıoğlu, K. (2018): Comparison of adaptive neuro-fuzzy inference system, artificial neural networks and non-linear regression for bark volume estimation in brutian pine (Pinus brutia Ten.). - Applied ecology and environmental research 16(2): 20152027.

[16] Çelik, S. (2004): Zeminlerde Gerilme ve Deformasyon Özelliklerinin Yapay Sinir Ağları İle Modellenmesi. - Doktora Tezi, Atatürk Üniversitesi Fen Bilimleri Enstitüsü.

[17] Dağl1, C. H. (1994): Artificial neural networks for intelligent manufacturing. - Operating Research Journal 6(1): 1-26. Turkey.

[18] Demuth, H., Beale, M., Hagan, M. (2009): Neural Network Toolbox User's Guide. - The MathWorks, Inc., Natrick, USA.

[19] Diamantopoulou, M. J. (2005a): Artificial neural networks as an alternative tool in pine bark volume estimation. - Computers and Electronics in Agriculture 48: 235-244. 
[20] Diamantopoulou, M. J. (2005b): Predicting fir trees stem diameters using Artificial Neural Network models. - Southern Forests: a journal of Forestry Science 205: 39-44.

[21] Diamantopoulou, M. J., Milios, E. (2010): Modelling total volume of dominant pine-trees in reforestations via multivariate analysis and artificial neural network models. Biosystems Engineering 105: 306-315.

[22] Diamantopoulou, M. J., Özçelik, R. (2012): Evaluation of different modeling approaches for total tree-height estimation in Mediterranean Region of Turkey. - Forest Systems 21(3): 383-397.

[23] Dykstra, D. P., Heinrich, R. (1996): FAO Model Code of Forest Harvesting Practice. FAO Publications, Rome, $85142 \mathrm{p}$.

[24] Ercanl1, İ., Kahriman, A., Yavuz, H. (2016): Predicting Oriental Spruce and Scots Pine Tree Diameter Increments Based on Artificial Neural Network Located in Mixed Oriental Spruce-Scots Pine Stands at Trabzon and Giresun Forest District. - International Forestry Symposium (IFS 2016) Proceedings, 07-10 December: 554-558. Kastamonu/Turkey.

[25] Erdaş, O. (1986): Odun hammaddesi Uretimi, Bolmeden C1karma ve Taşıma Safhalarında Sistem Secimi. - Karadeniz Universitesi, Orman Fakültesi Dergisi, Cilt 9, Sayı 1-2, s. 91113, Trabzon.

[26] Esteban, L. G., Fernandez, F. G., de Palacios, P. (2009): MOE Prediction in Abies pinsapo boiss. Timber: application of an artificial neural network using non-destructive testing. - Computers and Structures 87: 1360-1365.

[27] FAO. (1982): Basic Technology in Forest Operations. - FAO Forestry Paper No: 31, Rome.

[28] Fausett, L. (1994): Fundamentals of neural networks. Architectures, algorithms and applications. - Prentice Hall, USA, 461p.

[29] GDF. General Directorate of Forestry (2017): Activities of 2013 Year Report. - 100 p., Ankara.

[30] Ghajar, I., Najafi, A., Torabi, S. A., Khamehchiyan, M., Boston, K. (2012a): An adaptive network-based fuzzy inference system for rock share estimation in forest road construction. - Croatian Journal of Forest Engineering 33(2): 313-328.

[31] Ghajar, I., Najafi, A., Torabi, S. A., Boston, K. (2012b): Rock share estimation in forest road excavation using the Ordinal Logistic Regression (OLR) and the Analytical Hierarchy Process (AHP). - Iranian Journal of Forest and Poplar Research 20(2): 313323.

[32] Ghorbani, M. A., Zadeh, H. A., Isazadeh, M., Terzi, Ö. (2016): A comparative study of artificial neural network (MLP, RBF) and support vector machine models for river flow prediction. - Environ Earth Sci 75: 476.

[33] Guan, B. T., Gertner, G. (1991): Modeling red pine tree survival with an artificial neural network. - Forest Science 37(5): 1429-1440.

[34] Güngör, İ., Kayacan, M. C., Korkmaz, M. (2004): Artificial Neural Networks Use In The Forecasting Of Industrial Wood Demand And Comparıson With Different Estimation Methods. - YA/EM'2004 - Yöneylem Araştırmasi/Endüstri Mühendisliği - XXIV Ulusal Kongresi, 15-18 Haziran, Gaziantep - Adana.

[35] Haarlaa, R., Jurvelius, M. (1987): Choice of Appropriate Tools and Equipment For Mountain Forestry in Developing Countries. - IUFRO Symposium on the Role of Forest Research in Solving Socioeconomic Problems in the Himalayan Region, 17- 27.10.1987, Peshawar, Pakistan.

[36] Hasenauer, H., Merkl, D., Weingartner, M. (2001): Estimating tree mortality of Norway spruce stands with neural networks. - Advances in Environmental Research 5(4): 405414.

[37] Haykin, S. (1994): Neural Networks: A Comprehensive Foundation. - Macmillan, N. York, USA.

[38] Heinimann, H. R. (1999): Ground-Based Harvesting Systems for Step Slopes. - In: Sesssions, J., Chung, W. (eds.) Proceedings International Mountain Logging and 10th 
Pacific Northwets Skyline Symposium. Corvallis OR, March 28 - April 1, 1999: 1- 19. Oregon State University.

[39] Heinimann, H. R., Stampfer, K. (2003): Harvest Layout Plannıng for High-Altitude Protection Forests. - Austro2003: High Tech Forest Operations for Mountainous Terrain, October 5-9, Schlaegl, Austria.

[40] Hocking, R. R. (1986): The Analysis and Selection of Variables in Linear Regression Biometrics.

[41] Jensen, J., Qiu, F., Ji, M. (1999): Predictive modelling of coniferous forest age using statistical and artificial neural network approaches applied to remote sensor data. International Journal of remote sensing 20(14): 2805-2822.

[42] Karaman, A. (1997): Determining The Effect of Working Difficulties on The Production and The Study on These Factors Relating The Logging Operations on The Working Conditions in The East Karadeniz Forest Region. - 222 p, PhD Thesis, Karadeniz Technical University, Graduate School of Natural and Applied Sciences Trabzon-Turkey.

[43] Karaman, A. (2001): Wood raw material felling and transportation. - Published Lecture, Publish No: 4 (p. 263). Artvin, Turkey: Kafkas University, Artvin Forest of Faculty.

[44] Karaman, A., Çalışkan, E. (2009): Affective factors weight estimation in tree felling time by artificial neural networks. - Expert Systems with Applications 36: 4491-4496.

[45] Law, R., Au, N. (1999): A Neural Network Model to Forecast Japanese Demand for Travel to Hong Kong. - Tourism Management, 20.

[46] Leite, H. G., Marques da Silva, M. L., Binoti, D. H. B., Fardin, L., Takizawa, F. H. (2011): Estimation of inside-bark diameter and heartwood diameter for Tectona grandis Linn. trees using artificial neural networks. - European Journal of Forest and Research 130: 263-269.

[47] Marchi, E., Picchio, R., Spinelli, R., Verani, S., Venanzi, R., Certini, G. (2014): Environmental impact assessment of different logging methods in pine forests thinning. Ecol. Eng. 70: 429-436.

[48] Naghdi, R., Ghajar, İ. (2012): Application of Artificial Neural Network in the Modeling of Skidding Time Prediction. - Advanced Materials Research 403-408(2): 3538-3543.

[49] Özçelik, R., Diamantopoulou, M. J., Wiant, H. R., Brooks, J. R. (2008): Comparative study of Standard and modern methods for estimating tree bole volume of three species in Turkey. - Forest Products Journal 58(6): 73-81.

[50] Özçelik, R., Diamantopoulou, M. J., Wiant, H. V., Brooks, J. R. (2010): Estimating tree bole volume using artificial neural network models for four species in Turkey. - Journal of Environmental Management 91(3): 742-753.

[51] Özçelik, R., Diamantopoulou, M. J., Crecente-Campo, F., Eler, U. (2013): Estimating Crimean juniper tree height using nonlinear regression and artificial neural network models. - Forest Ecology and Management 306: 52-60.

[52] Öztemel, E. (2003): Yapay Sinir Ağları - Papatya yayıncılık, İstanbul.

[53] Öztürk, T., Demir, M. (2005): Work performance of MB Trac 900 tractor on mountainous terrain in Turkey. - American Journal of Applied Sciences 2(1): 363-366.

[54] Öztürk, T. (2010): Productivity of MB Trac 900 tractor at beech stands on mountainous areas in Blacksea Region. - African Journal of Agricultural Research 5(1): 28-33.

[55] Öztürkcan, M. (2009): Regresyon Analizi. - Maltepe Üniversitesi Yayınları Sayı:3, No:40.

[56] Pentek, T., Porinsky, T., Sunjar, M., Stanki, İ., Nevecerel, H., Sporcic, M. (2008): Environmentally Sound Harvesting Technologies in Commercial Forests in the Area of Northern Velebit Functional Terrain Classification. - Periodicum Biologorum 110(2): 127-135.

[57] Rumelhart, D. E., Hinton, G. E., Williams, R. J. (1986): Learning internal representations by error propagation. - In: Rumelhart, D. E., McClelland, J. L. \& Corporate PDP Research Group (eds.) Parallel distributed processing. MA, USA: MIT Press. pp. 318362. 
[58] Sağıroğlu, Ş., Beşdok, E., Erler, M. (2003): Mühendislikte Yapay Zekâ Uygulamaları I: Yapay Sinir Ağları. - Ufuk Kitabevi. Kayseri.

[59] Seckin, O. B. (1978): Demirkoy Karamanbayırı Devlet Orman işletmesi Cakmaktepe Bolgesi Yol Şebekesinin Planlama Tekniği Bakımından Araştırılması. - OGM Yayınları No: 622/132, İstanbul.

[60] Topçu, İ. B., Sarıdemir, M. (2008): Prediction of Compressive Strength of Concrete Containing Fly Ash Using Artificial Neural Networks and Fuzzy Logic. - Computational Materials Science 41: 305-311.

[61] Tunay, M., Melemez, K. (2002): Bölmeden çıkarma çalışmalarında tarım ve orman traktörlerinin verim karşılaştırması (Karabük işletmesi örneği). - II. Ulusal Karadeniz Ormanc1lık Kongresi Bildiriler Kitabı, Kafkas Üniversitesi Orman Fakültesi, 1:401-410.

[62] Yeşilnacar, E., Topal, T. (2005): Landslide susceptibility mapping: a comparison of logistic regression and neural networks methods in a medium scale study, Hendek region (Turkey). - Engineering Geology 79: 251-266.

[63] Yıldız, B. (2001): Finansal Başarısızlığın Öngörülmesinde Yapay Sinir Ağı Kullanımı ve Halka Açık Şirketlerde Ampirik Bir Uygulama. - İMKB Dergisi 17: 50-59.

[64] Yilmaz, I. (2009): Landslide susceptibility mapping using frequency ratio, logistic regression, artificial neural networks and their comparison: A case study from Kat landslides (Tokat-Turkey). - Computers \& Geosciences 35: 1125-1138.

[65] Yu, H., Wilamowski, B. (2011): Levenberg-marquardt training. - The Industrial Electronics Handbook, 1-16.

[66] Yurtoğlu, H. (2006): Yapay sinir ağlan metodolojisi ile öngörü modellemesi. - Uzmanlık Tezi, Yıldız Teknik Üniversitesi, Sosyal Bilimler Enstitüsü, İstanbul. 